\title{
AZ ÖRVÖS GALAMB (Columba palumbus) FÉSZKELÖHELY-HASZNÁLATÁNAK SAJÁTOSSÁGAI URBÁN KÖRNYEZETBEN
}

\author{
Juhász Lajos \& Varga Sámuel Zsolt
}

\begin{abstract}
Debreceni Egyetem Mezőgazdaság-, Élelmiszertudományi és Környezetgazdálkodási Kar, Állattudományi, Biotechnológiai és Természetvédelmi Intézet, Természetvédelmi Állattani és Vadgazdálkodási Tanszék University of Debrecen, Faculty of Agricultural and Food Sciences and Environmental Management, Institute of Animal Science, Biotechnology and Nature Conservation,

Department of Nature Conservation, Zoology and Game Management H-4032 Debrecen, Böszörményi út 138., Hungary; e-mail: varga.samuel@agr.unideb.hu, juhaszl@agr.unideb.hu
\end{abstract}

\begin{abstract}
JUHÁSZ L. \& VARGA S. ZS. (2019): NEST-SITE USE CHARACTERISTICS OF COMMON WOOD PIGEONS (Columba palumbus) IN AN URBAN ENVIRONMENT. Hungarian Small Game Bulletin 14: 131-139. http://dx.doi.org/10.17243/mavk.2019.131

As urbanization among bird species increases, among passerines, columbid species are evolving in urban habitats. The Common Wood Pigeon (Columba palumbus) is a wide-spread columbid species in Europe, which has a still ongoing urbanization process in Hungary. The success of this phenomenon depends on the nutrient and nesting resources represented in urban habitats. This paper has the goal to collect sufficient data on the nestsite use characteristics of the native species Common Wood Pigeon in an urban ecosystem. During the research a survey was made on 150 nests observed on 19 tree species/genera to determine the tree species composition, the average height that are used by these birds. In addition, descriptive factors were also recorded such as horizontal position of the nest, habitat type, and the traffic intensity as well.
\end{abstract}

KULCSSZAVAK: urbanizáció, városi vadgazdálkodás, Columbidae, Columba palumbus, városökológia

KEY WORDS: urbanization, urban game management, Columbidae, Columba palumbus, urban ecology

\section{BEVEZETÉS}

\subsection{AZ ÖRVÖS GALAMB ELTERJEDÉSE, ÁLLOMÁNYVISZONYAI}

Az örvös galamb egy széleskörben elterjedt galambféle Európában, élőhelye Oroszországtól a mediterrán félszigetekig, illetve Észak-Afrikáig tart. Az elmúlt évtizedekben a faj kiterjesztette a fészkelőterületét Észak-Európa felé, ezzel egyetemben a legtöbb nyugateurópai országban is a fészkelés gyakorisága növekedett. Európa-szerte vadászható faj, azonban állománya stabilnak tekinthető, ezt bizonyítja a faj növekvő állománya a 20. század utolsó negyede óta. Európai állománya 51-73 millió egyedre tehető (BIRDLIFE INTERNATIONAL 2018). Hazai fészkelö-állománya 49000 - 116000 párra tehető (2000-2012) és az ezredforduló óta erős növekedést mutat (MME 2019). Az eredeti fészkelőhelyén kívül az örvös galamb városi kolonizációja is felerősödött.

\subsection{KITEKINTÉS A FAJ EURÓPAI URBANIZÁCIÓJÁRA}

A faj urbanizációja elsők között Nagy-Britanniában ment végbe, ahol a vadon élő állomány növekedésével párhuzamosan növekedő városi állományokat észleltek (MARCHANT et al. 
1990). Az állomány kezdetben megsínylette az őszi vetésü herefélék (Trifolium sp.) vetésterületeinek visszaszorulását az 1950-es és 1960-as években (INGLIS et al. 1990, 1994), amely elsődleges téli táplálékaként ismert. Az 1970-es évek közepén termelésbe vont repce (Brassica napus) újra növekvő állománysürüséget eredményezett (INGLIS et al. 1990, 1994), a nagymértékü gyarapodás eredménye: az eredetileg galériaerdőket elfoglaló örvös galamb egyre nagyobb számban jelent meg városi parkok fáin (HARDY 1986, SLATER 1995).

Finnországban az 1967. évi adatok szerint 12 új faj városiasodását észlelték. Többek közt a nagy fülemüle, szajkó, feketerigó, kis poszáta, örvös galamb és néhány vízimadár városi megjelenését dokumentálták (TENOVUO 1967). Ekkor még szórványosan, 1991-ben már tömegesen észleltek városban költő örvös galambokat Finnország több területén, főleg a tengerparti településeken (FEY et al. 2014). Elterjedésének keleti határán, Oroszországban a városi ökoszisztémában már magasabb az állománysürüség, mint a környező, korábban tipikus erdei élőhelyeken (BEA et al. 2011).

\subsection{A FAJ URBANIZÁCIÓJÁNAK MÉRFÖLDKÖVEI MAGYARORSZÁGON}

GRESCHIK (1929) észlelte Magyarországon elsőként az örvös galamb fészkelését Kaposvár vasútállomásán, azonban a robbanásszerü városiasodás az 1980-as évektől jelentkezett, főként Dunántúlon, a Balaton környéki strandokon, nyaraló övezetekben, de már a fövárosban a Népliget és a Margit-sziget területein is észleltek költő örvös galamb párokat (RÉKÁSI 2000). Az 1990-es években már egyre gyakoribb fészkelővé vált, korábbi óvatos viselkedése megváltozott, szelídebbé vált, ahogy ezt SCHMIDT (1994) is kifejtette, illetve felhívta a figyelmet az erősödő urbanizációra. Első sikeres költéseik kisebb vidéki településekhez köthetők, így elsők között Vácon (DREXLER 1995), Kömlőn (AMBRUS 1996), és Foktőn (SIPOS 1995) dokumentáltak sikeresen felnevelt örvös galamb fészekaljakat. A hazai urbanizáció kezdődő csúcspontját a faj épületeken történő fészkelése jelentette, amelyet 2008-ban PROMMER (2008) észlelt az esztergomi bazilikán, ezt követte BANKOVICS (2019) megfigyelése, aki elsőként számolt be sikeres épületen való költésről a fővárosból.

\subsection{CÉLKITŰZÉSEK}

Jelen tanulmány célja feltárni, hogy a fészkek elhelyezkedése miképpen változik eltérő emberi jelenlét mellett városi ökoszisztémában, illetve van-e bárminemü kapcsolat a fészkelési sajátosságok, különösképpen a fészek magassága és a városi élőhelyet leíró föbb tényezők között, úgy, mint beépítettség szintje, vagy a környező gépjármüforgalom sürüsége.

\section{ANYAG ÉS MÓDSZER}

\subsection{A FELMÉRÉS HELYE, IDŐTARTAMA}

A felmérést Debrecenben, tipikus élöhelyeken (városi biotópokban, JUHÁsZ 1985), összesen 10 mintavételi négyzetben végeztük el, 2019. február 1. és március 31 . között. A terepi munka során egyszerre mértük fel a fészkek elhelyezkedését és sürüségét, valamint a város tipikus élőhelyeit. Felvételezésre kerültek a megfigyelt fészkek építési magassága és horizontális pozíciója a törzshöz képest, a fészkelésre kiválasztott fafaj/nemzetség és annak magassága, valamint kategorizálásra került a környezet forgalom-terhelése is. A magassági értékeket CHRISTEN-féle magasságmérővel becsültük, majd lézeres távolságmérővel ellenőriztük. Emellett összesen hat különböző élőhelytípust és négy forgalmi intenzitási kategóriát különítettünk el munkánk során. 


\subsection{AZ ADATOK ÉRTÉKELÉSE}

Az adatokat a gyüjtés és rendszerezés után kiértékeltük. A leíró statisztikai elemek mellett, t-próbával, $\chi^{2}$-próbával, PEARSON korrelációval hasonlítottuk össze, az egyes skála típusú változókat, a kategóriákat pedig SPEARMAN rang-korrelációval vetettük össze. Az egyes élőhelyek közti különbségeket varianciaanalízissel és LSD post-hoc teszttel vizsgáltuk. Ezen felül Általános Lineáris Modellt állítottunk fel a fészkelőhely használat során fellépö lehetséges összefüggések, kovarianciák felderítésére. Az értékeléshez SPSS 25.0 szoftvert használtunk.

\section{EREDMÉNYEK}

\subsection{A FÉSZEK ELHELYEZKEDÉSE A FELMÉRT FAEGYEDEKEN}

A munkánkból kiderült, hogy a fészkelésre használt faegyedek átlagos magassága a belvárosban volt a legmagasabb, ettől kifelé haladva csökkent a használt faegyedek átlagos magassága oly mértékben, hogy a belvárosiakétól minden esetben szignifikáns $(* p<0,05)$ eltérést mutatott (1. táblázat). A fészek helyének magassága, mint elsődleges fészkelési jellemző a beépítettség függvényében eltérő értékeket produkált a felmérés során. A magasabb beépítettségü belvárosi területeken szignifikánsan magasabban $(* p \quad<0,05)$ helyezkedtek el a fészkek, mint a magasabb természetességü területeken (2. táblázat). A forgalom intenzitásának is meghatározó szerepe van a fészek magasságában: minél intenzívebb a forgalom, annál magasabbra épülnek a fészkek a fákon (1. ábra).

\section{1. táblázat: Fészkelésre használt faegyedek városi élőhelyek szerinti átlagos} famagasságainak különbségei (m)

Table 1: Differences of mean height of tree specimens used for nesting by Common Wood Pigeons between the urban habitat types $(m)$

\begin{tabular}{|c|c|c|c|c|c|c|c|}
\hline \multirow{2}{*}{$\begin{array}{c}\text { Élöhely } \\
\text { Habitat types }\end{array}$} & \multirow{2}{*}{$\begin{array}{l}\text { Átlag } \\
(\mathrm{m}) \\
\text { Mean }\end{array}$} & \multicolumn{6}{|c|}{$\begin{array}{c}\text { Fészkelésre használt faegyedek városi élöhelyek szerinti átlagos } \\
\text { famagasságainak különbségei }(\mathbf{m}) \\
\text { Differences of mean height of tree specimens used for nesting by Common Wood } \\
\text { Pigeons between the urban habitat types }(\mathrm{m})\end{array}$} \\
\hline & & $\begin{array}{c}\text { Belváros } \\
\text { Downtown }\end{array}$ & $\begin{array}{c}\text { Ipari park } \\
\text { Industrial } \\
\text { park }\end{array}$ & $\begin{array}{c}\text { Lakótelep } \\
\text { Housing } \\
\text { estate }\end{array}$ & $\begin{array}{l}\text { Kertváros } \\
\text { Suburb }\end{array}$ & $\begin{array}{c}\text { Városi } \\
\text { park City } \\
\text { park }\end{array}$ & $\begin{array}{c}\text { Városszél } \\
\text { Edge of the } \\
\text { city }\end{array}$ \\
\hline $\begin{array}{c}\text { Belváros } \\
\text { Downtown }\end{array}$ & 23,1 & 0 & $9,6^{*}$ & $11,1^{*}$ & $10,14^{*}$ & $7,8^{*}$ & $11,19^{*}$ \\
\hline $\begin{array}{c}\text { Ipari park } \\
\text { Industrial park }\end{array}$ & 13,5 & & 0 & 1,5 & 0,54 & $-1,8$ & 1,59 \\
\hline $\begin{array}{c}\text { Lakótelep } \\
\text { Housing estate }\end{array}$ & 12,0 & & & 0 & $-0,96$ & $-3,3$ & 0,09 \\
\hline $\begin{array}{c}\text { Kertváros } \\
\text { Suburb }\end{array}$ & 13,0 & & & & 0 & $-2,34$ & 1,05 \\
\hline $\begin{array}{l}\text { Városi park } \\
\text { City park }\end{array}$ & 15,3 & & & & & 0 & 3,39 \\
\hline $\begin{array}{c}\text { Városszél } \\
\text { Edge of the city }\end{array}$ & 11,9 & & & & & & 0 \\
\hline
\end{tabular}

$*: \mathrm{p}<0,05$ 
2. táblázat: Élőhely szerinti átlagos fészekmagasságok különbségei (m)

Table 2: Differences mean height of nests of Common Wood Pigeons between the urban habitat types $(m)$

\begin{tabular}{|c|c|c|c|c|c|c|c|}
\hline \multirow{2}{*}{$\begin{array}{c}\text { Élőhely } \\
\text { Habitat types }\end{array}$} & \multirow{2}{*}{ átlag (m) } & \multicolumn{6}{|c|}{$\begin{array}{c}\text { Élöhely szerinti átlagos fészekmagasságok különbségei (m) } \\
\text { Differences mean height of nests of Common Wood Pigeons between the urban } \\
\text { habitat types }(\mathrm{m})\end{array}$} \\
\hline & & $\begin{array}{c}\text { Belváros } \\
\text { Downtown }\end{array}$ & $\begin{array}{l}\text { Ipari park } \\
\text { Industrial } \\
\text { park }\end{array}$ & $\begin{array}{l}\text { Lakótelep } \\
\text { Housing } \\
\text { estate }\end{array}$ & $\begin{array}{l}\text { Kertváros } \\
\text { Suburb }\end{array}$ & $\begin{array}{l}\text { Városi } \\
\text { park City } \\
\text { park }\end{array}$ & $\begin{array}{l}\text { Városszél } \\
\text { Edge of the } \\
\text { city }\end{array}$ \\
\hline $\begin{array}{c}\text { Belváros } \\
\text { Downtown }\end{array}$ & 17,6 & 0 & $8,79 *$ & $10,46^{*}$ & $7,9 *$ & 4,9 & $8,62 *$ \\
\hline $\begin{array}{c}\text { Ipari park } \\
\text { Industrial park }\end{array}$ & 8,8 & & 0 & 1,67 & $-0,89$ & $-3,89$ & $-0,17$ \\
\hline $\begin{array}{c}\text { Lakótelep } \\
\text { Housing estate }\end{array}$ & 7,2 & & & 0 & $-2,56$ & $-5,56$ & $-1,84$ \\
\hline $\begin{array}{c}\text { Kertváros } \\
\text { Suburb }\end{array}$ & 9,7 & & & & 0 & -3 & 0,72 \\
\hline $\begin{array}{l}\text { Városi park } \\
\text { City park }\end{array}$ & 12,7 & & & & & 0 & 3,72 \\
\hline $\begin{array}{c}\text { Városszél } \\
\text { Edge of the city }\end{array}$ & 9,0 & & & & & & 0 \\
\hline
\end{tabular}

$*: \mathrm{p}<0,05$

A városi populáció teljes egészére kivetítve a fészekmagasság három felmért tényezővel szemben mutatott korrelációt. A metrikus változók közül a famagassággal, illetve a fészek horizontális pozíciójával és a forgalom intenzitásával (3. táblázat).

A fészkek gépjármüforgalomra adott válasza az alacsony és elhanyagolható zavarás felé tolódott el, a fészkek 71,3\%-a $(n=107)$ ezekbe a kategóriákba esett, a fészek száma a zavarás csökkenésének mértékében nőtt. Tekintettel arra, hogy a városban az elhanyagolható forgalmú utcák száma elenyésző, nem tekinthető kiugró értéknek az alacsony kategória ilyen mértékü túlsúlya a többi kategóriához képest, sokkal inkább annak a megerősítése, hogy a fészkek a kevésbé zavart környezetben voltak nagyobb számban a felmért területen (1. ábra).

Az elhanyagolható (az összes felmért fészek 24,7\%-a) és közepes kategória (20\%) gyakorisága között az abszolút távolság kevesebb, mint 5\%, így azok nem különböznek egymástól szignifikánsan.

3. táblázat:A fészekmagassággal összefüggésbe hozható faktorok korrelációs együtthatói Table 3: Correlation coefficients for factors that are associated with nest height

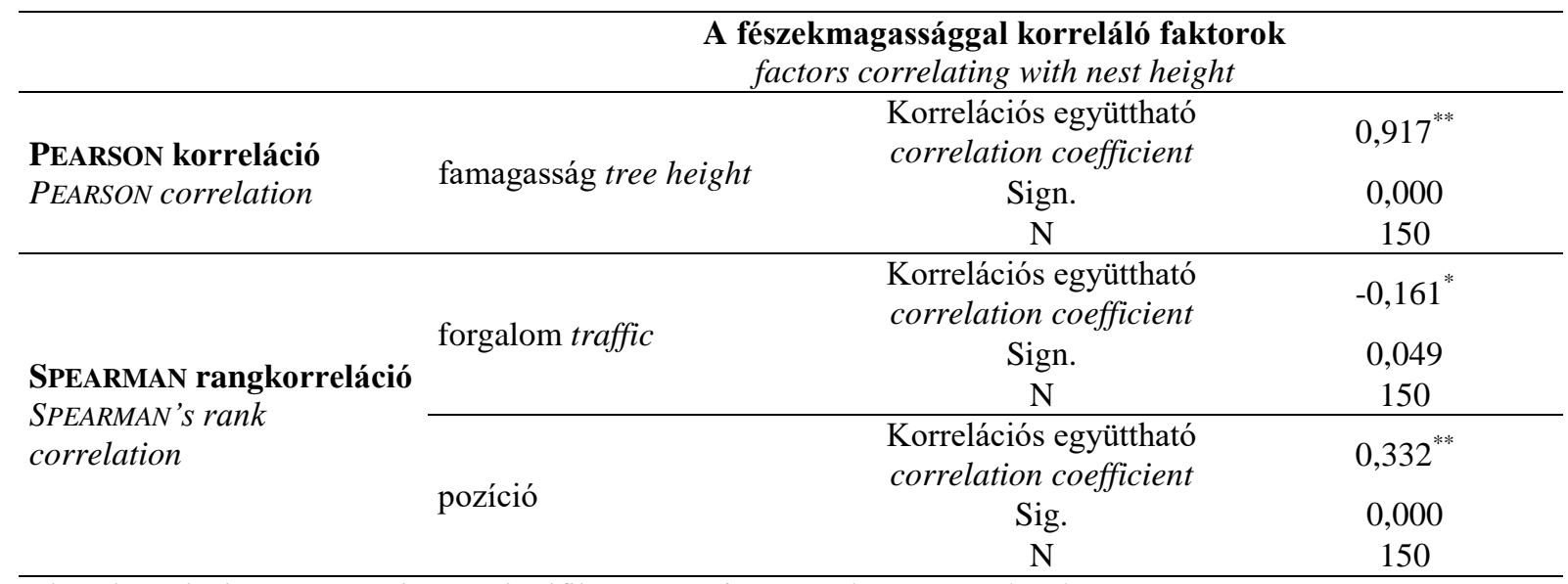

*. A korreláció $\mathrm{p}<0.05$ szinten szignifikáns significant at the $p<0.05$ level

**. A korreláció $\mathrm{p}<0.01$ szinten szignifikáns significant at the $p<0.01$ level 


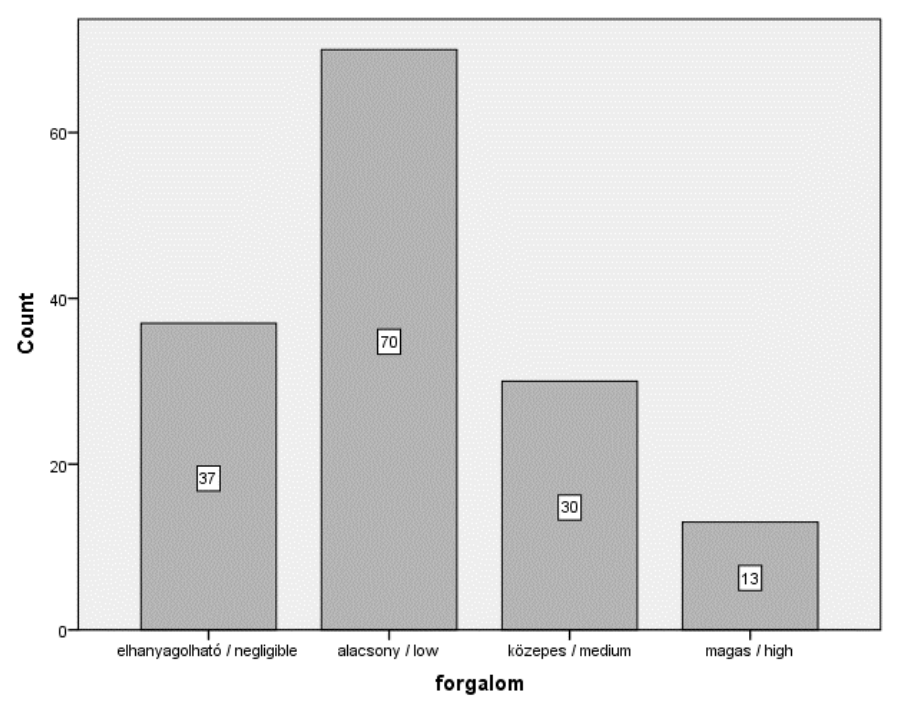

1. ábra: Az örvös galamb fészkek megoszlása a forgalom intenzitásának függvényében

Figure 1: Distribution of Common Wood Pigeon nests plotted against traffic intensity

A fészkek horizontális elhelyezkedése (2. ábra) szerint a felmért fészkeket - eddigi ismeretinkkel összhangban - inkább az ágvégi régióban építették az örvös galambok, bár jelentős különbség nem tapasztalható az egyes kategóriák között, mégsem tekinthetők homogén eloszlásúnak a vizsgált sokaságban $\left(\chi^{2}\right.$-próba: $\left.\chi^{2}: 6,04, p=0.049\right)$.

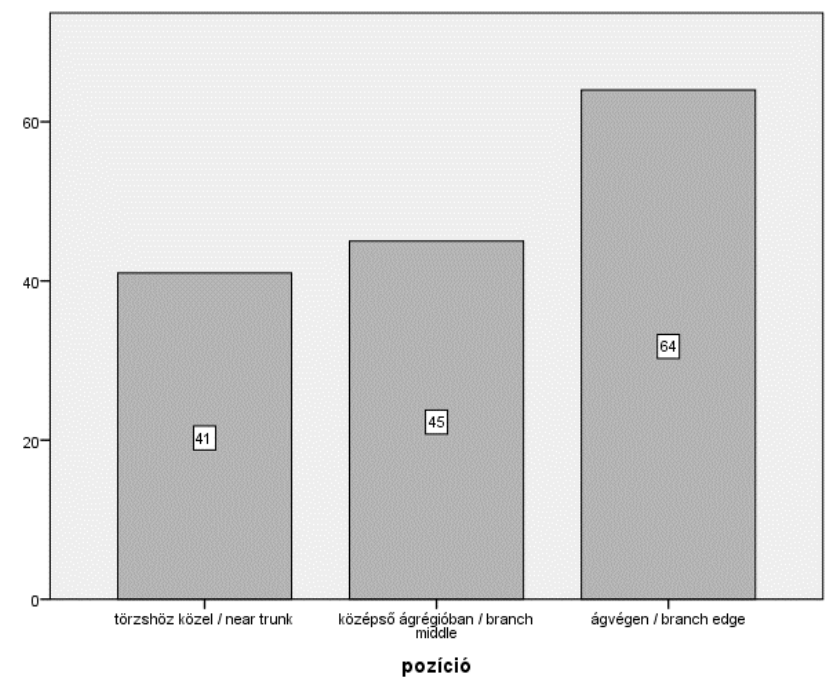

2. ábra: A felmért örvös galamb fészkek horizontális elhelyezkedésének megoszlása Figure 2: Distribution of the horizontal location of the Common Wood Pigeon nests

\subsection{A FÉSZKEK ÉS A FAFAJOK KAPCSOLATA}

Összesen 19 fafajon figyeltünk meg fészkeket, a három leggyakrabban használt faj/fajcsoport a Celtis occidentalis $(22,66 \%, n=34)$, a Tilia sp. $(15,33 \%, n=23)$ és az Acer sp. $(14,66 \%, n=22)$ volt a 150 megfigyelt fészek esetén (4. táblázat). A génuszok összevonását indokolta a faegyedek hasonló habitusa, amely fészkelési szempontból relevánsabb, mint a fajszintü megkülönböztetés. Az első három fafaj megfelel a városban telepített fák gyakoriságának. 
4. táblázat: Az egyes fafajok használtsága és leíró statisztikai mutatói a famagasság és fészekmagasság függvényében

Table 4: Use and descriptive statistical parameters of different tree species depending on the tree height and height of nests

\begin{tabular}{|c|c|c|c|c|c|c|c|c|c|}
\hline \multirow{2}{*}{$\begin{array}{l}\text { Faj/génusz } \\
\text { Species/genus }\end{array}$} & \multicolumn{5}{|c|}{$\begin{array}{c}\text { Famagasság }(\mathrm{m}) \\
\text { tree height }\end{array}$} & \multicolumn{4}{|c|}{$\begin{array}{c}\text { Fészekmagasság }(\mathrm{m}) \\
\text { height of nests }\end{array}$} \\
\hline & $\mathrm{n}$ & $\begin{array}{l}\text { Átlag } \\
\text { Mean }\end{array}$ & Minimum & Maximum & $\mathrm{SD}$ & $\begin{array}{l}\text { Átlag } \\
\text { Mean }\end{array}$ & Minimum & Maximum & $\mathrm{SD}$ \\
\hline $\begin{array}{l}\text { Celtis } \\
\text { occidentalis }\end{array}$ & 34 & 18,07 & 8,0 & 30,0 & 7,51 & 13,76 & 4,0 & 25,0 & 7,19 \\
\hline Tilia sp. & 23 & 12,91 & 3,0 & 22,0 & 4,86 & 9,00 & 2,0 & 20,0 & 5,01 \\
\hline Acer sp. & 22 & 10,55 & 4,0 & 16,0 & 3,98 & 6,73 & 3,0 & 14,0 & 2,58 \\
\hline Platanus sp. & 13 & 18,31 & 8,0 & 30,0 & 7,19 & 13,38 & 5,0 & 28,0 & 7,31 \\
\hline Quercus robur & 12 & 15,42 & 6,0 & 22,0 & 5,78 & 12,79 & 5,0 & 20,0 & 5,93 \\
\hline Fraxinus sp. & 11 & 12,73 & 8,0 & 19,0 & 4,13 & 10,09 & 3,0 & 17,0 & 4,18 \\
\hline Carpinus betulus & 7 & 9,00 & 6,0 & 15,0 & 3,06 & 6,79 & 5,0 & 13,5 & 3,05 \\
\hline $\begin{array}{l}\text { Robinia } \\
\text { pseudoacacia }\end{array}$ & 7 & 11,14 & 8,0 & 18,0 & 4,02 & 8,71 & 6,0 & 13,0 & 3,09 \\
\hline Salix alba & 5 & 12,40 & 9,0 & 21,0 & 5,08 & 9,70 & 7,5 & 16,0 & 3,56 \\
\hline Gleditsia & 3 & 10,67 & 8,0 & 15,0 & 3,79 & 9,17 & 7,0 & 13,5 & 3,75 \\
\hline Populus sp. & 3 & 17,67 & 15,0 & 22,0 & 3,79 & 12,00 & 10,0 & 14,0 & 2,00 \\
\hline Corylus avellana & 2 & 24,00 & 18,0 & 30,0 & 8,49 & 22,50 & 17,0 & 28,0 & 7,78 \\
\hline Juglans regia & 2 & 11,00 & 9,0 & 13,0 & 2,83 & 8,25 & 7,0 & 9,5 & 1,77 \\
\hline $\begin{array}{l}\text { Aesculus } \\
\text { hippocastanum }\end{array}$ & 1 & 28,00 & 28,0 & 28,0 & & 27,00 & 27,0 & 27,0 & \\
\hline Betula pendula & 1 & 10,00 & 10,0 & 10,0 & & 8,00 & 8,0 & 8,0 & \\
\hline Pinus sylvestris & 1 & 11,00 & 11,0 & 11,0 & & 9,00 & 9,0 & 9,0 & \\
\hline $\begin{array}{l}\text { Sophora } \\
\text { japonica }\end{array}$ & 1 & 17,00 & 17,0 & 17,0 & & 16,00 & 16,0 & 16,0 & \\
\hline Catalpa sp. & 1 & 15,00 & 15,0 & 15,0 & & 11,00 & 11,0 & 11,0 & \\
\hline $\begin{array}{l}\text { Ulmus pumila } \\
\text { 'Turkestan' }\end{array}$ & 1 & 17,00 & 17,0 & 17,0 & & 14,00 & 14,0 & 14,0 & \\
\hline Összesen Total & 150 & 14,42 & 3,0 & 30,00 & 6,43 & 10,86 & 2,0 & 28,0 & 6,08 \\
\hline
\end{tabular}

\subsection{A MODELLEZÉS EREDMÉNYE}

Az általános lineáris regressziós modellbe a fentiek alapján a famagasságot, a forgalmat, és a fészek horizontális elhelyezkedését vontuk be faktorként. A modell kidolgozása során ,forward-stepwise" módszert alkalmaztunk. A végleges modell 85,6\%-os pontosságú, a bevont prediktorok 96\% (famagasság, $p<0,05$ ), 3\% (forgalom, $p<0,05$ ) és 1\% (pozíció, nem szignifikáns) arányban voltak fajsúlyosak. Azaz, a fészkelésre használt fákon a fészekmagasság megválasztását elsődlegesen a faegyed magassága határozta meg, ezt kis mértékben befolyásolta a környező gépjármüforgalom. 


\section{4. ÉRTÉKELÉS}

\subsection{A FAFAJ, MINT ÖKOLÓGIAI TÉNYEZÖ}

Bár HARASZTHY (2019) a faj költésbiológiájának ismertetése során utalt a vadon élő egyedek fafaj-igényére, ez városi környezetben nem állja meg a helyét. Korábban 34 fészek adatai alapján 14 faj, illetve génusz került meghatározásra, valamint egyedi városi megfigyelések preferenciát véltek felfedezni több fafaj használatában. Tapasztalataink alapján azonban városi környezetben sokkal inkább a faegyed általános habitusa, ágsürüsége, illetve a környező zavaró forrásoktól való távolsága a fajsúlyosabb a fészek helyének kiválasztásakor.

\subsection{A FÉSZEKMAGASSÁG ÉS AZ URBÁN KÖRNYEZET KAPCSOLATA}

A fészkek jellemző tulajdonságai közül a legjelentősebb annak talajtól mért magassága. Ha szemrevételezünk egy áltagos vadon, azaz nem városi körülmények közt felmért populációt, a fészekmagasság átlagosan 2-8 méter közötti értéket mutat, ezen belül is túlnyomórészt a 2-5 m mondható tipikusnak. (SOLTI 2010 alapján) Ezzel szemben a városi populáció költőpárjai fészkeiket magasabbra ( $t$-próba: $\mathrm{t}=-15,22 ; p<0,01), 5-10$ méteres magasságba rakják, és nem ritkák a kiugróan magas elhelyezkedésü fészkek sem (3. ábra).

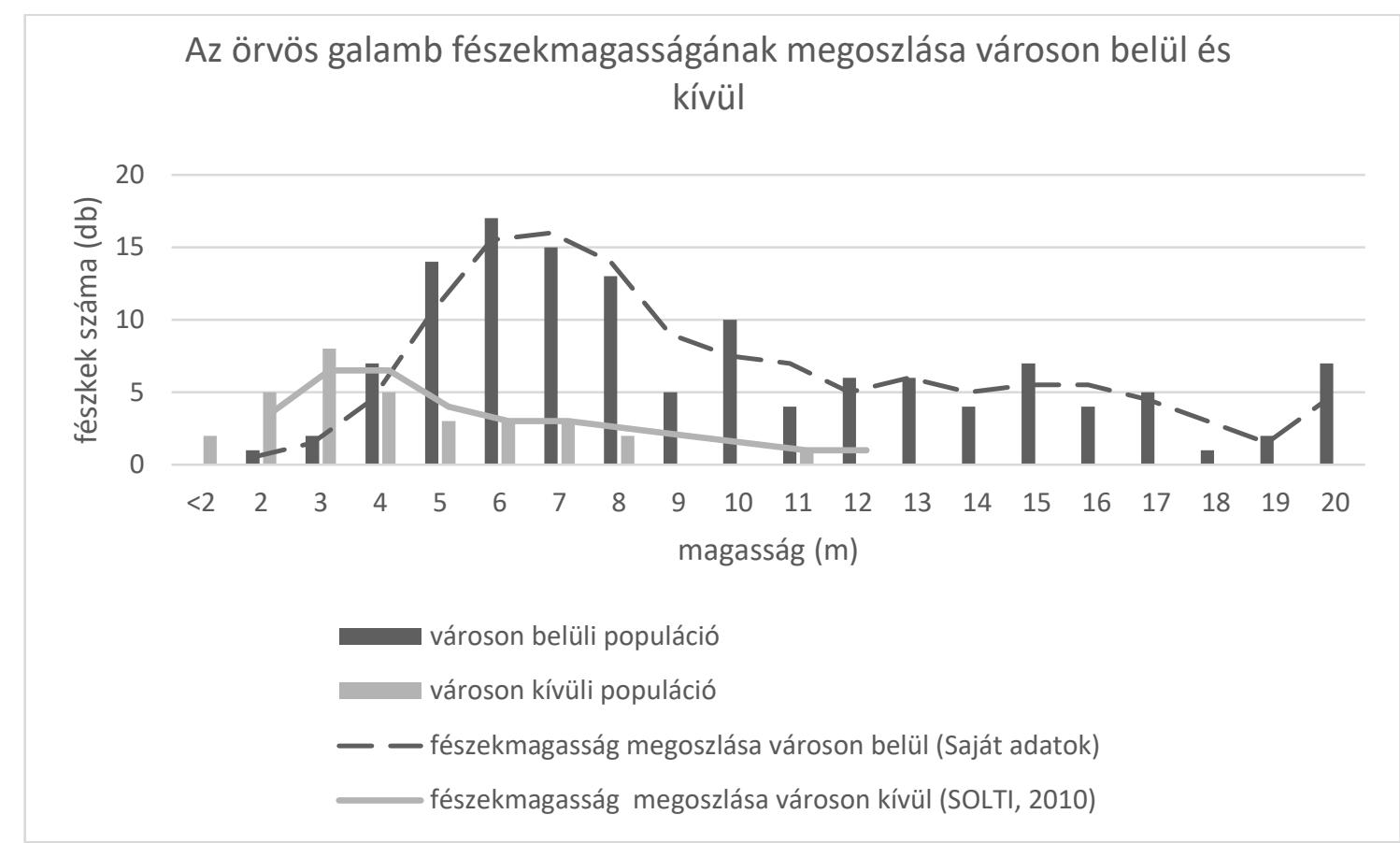

3. ábra: Az örvös galamb fészekmagasságának megoszlása városon belül és kívül

Figure 3: Distribution of nest height of Common Wood Pigeon inside and outside the city

Ennek okát több tényező együttes hatásaként jellemezhetjük: egyrészt a városi élőhelyek fái erősen befolyásoltak különféle faápolási munkákkal (gallyazás, ritkítás, az alsó ágak visszavágása a zavartalan közlekedés biztosításáért), valamint a fokozott emberi zavarással indukált fokozott óvatosság, ami az örvös galambok fészkelési jellemzőire is kihat.

\subsection{A KUTATÁS TOVÁBBI LEHETőSÉGEI}

A fentiekből látható eredmények további bővítéséhez szükséges lenne egy újabb komplex felmérés elvégzése, amelyben városon kívül élő egyedek fészkelöhely választását 
(preferenciáját) hasonlítanánk össze városi populációkéval. Ezen felül a városok faleltárját, és a fészkelésre elfoglalt fákat összehasonlítva egy városi fafaj-preferencia is elérhetővé válhat az örvös galamb esetében. Különösen értékes lehetne az idegenhonos, vagy invazív fafajok szerepe a galambfélék, és más madárfajok városiasodásában, így nagyobb fókusz helyeződhet pl. a turkesztáni szil (Ulmus pumila 'Turkestan'), illetve más, tipikus „parkfa-fajok” jelentőségének vizsgálatára. Jelen kutatás során nem volt hangsúlyos a fészkek sürüségének behatóbb vizsgálata, ezért a téma térinformatikai jellegü megközelítése is nagy potenciált rejthet a faj urbán terjedési mintázatának hazai feldolgozásában. Városökológiai szempontból a városi ragadozók, jelen esetben a varjúfélék és az örvös galamb kapcsolatának megismerése is új csapásirány lehet.

\section{KÖSZÖNETNYILVÁNÍTÁS}

A publikáció elkészítését az EFOP-3.6.3-VEKOP-16-2017-00008 számú projekt támogatta. A projekt az Európai Unió támogatásával, az Európai Szociális Alap társfinanszírozásával valósult meg.

\section{IRODALOMJEGYZÉK}

AMBRUS B. (1996): Örvös galamb (Columba palumbus) költései Kömlő belterületén. Calandrella 10(1-2): 239-240.

BANKOVICS A. (2019): Adatok az örvös galamb (Columba palumbus LiNNAEUS, 1758) urbanizálódásához: az első épületen való fészkelések. Aquila 126: 25-32.

Bea A., Svazas S. , Grishanov G. , Kozulin A., Stanevicius V., Astafieva T. , Olano I. , Raudonikis L. , ButKauskas D. \& SRuoga A. (2011): Woodland and Urban Populations of the Woodpigeon Columba palumbus in the Eastern Baltic Region, Ardeola 58(2): 315-321. https://doi.org/10.13157/arla.58.2.2011.315 utolsó letöltés 2020. február 28.

BIRDLIFE INTERNATIONAL (2018): Columba palumbus. The IUCN Red List of Threatened Species 2018: e. T22690103A131924602. https://dx.doi.org/10.2305/IUCN.UK.20182.RLTS.T22690103A131924602.en. utolsó letöltés: 2020. január 27.

DreXLER, Sz. (1995): Örvös galamb (Columba palumbus) fészkelési kísérlete Vácon. Madártani Tájékoztató 1995 (január-június): 30.

Fey K., Vuorisalo T., LehiKoinen A., \& Selonen V. (2014): Urbanisation of the wood pigeon (Columba palumbus) in Finland, Landscape and Urban Planning 134 (February 2015): 188-194. https://doi.org/10.1016/j.landurbplan.2014.10.015, utolsó letöltés 2020. február 28.

GRESCHIK, J. (1929): Parkba telelő örvösgalambpár Kaposvárott. Kócsag 2(2): 85-86.

HARASZTHY, L. (2019): Örvös galamb Columba palumbus LinNAEUS, 1758. In: HARASZTHY L.: Magyarország fészkelö madarainak költésbiológiája 1. kötet. Fácánféléktől a sólyomfélékig (Non-Passeriformes). Pro Vértes Nonprofit Zrt., Csákvár, pp. 201-206.

HARDY, E. (1986): North Western Bird Report 1971-1985. Merseyside Naturalists Association.

INGLIS, I. R., ISAACSON, A. J. \& THEARLE, R. J. P. (1994): Long-term changes in the breeding biology of the Woodpigeon Columba palumbus in eastern England. Ecography 17: 182-188.

Inglis, I. R., IsAacson, A. J., Thearle, R. J. P. \& Westwood, N. J. (1990): The effects of changing agricultural practice upon Woodpigeon Columba palumbus. Ibis 132: 62-272. 
JuHÁSz, L. (1985): A Debrecen város ornithofaunájának synökológiai analízise. Puszta 3(12): $37-52$.

MME (2019): Örvös galamb. http://www.mme.hu/magyarorszagmadarai/madaradatbaziscolpal utolsó letöltés: 2020. január 27.

Marchant, J. H., Hudson, R., Carter, S. P. \& Whittington, P. (1990): Population Trends in British Breeding Birds. British Trust for Ornithology, Thetford.

MIECH P. (1988): Gabäudebruten der Ringeltaube (Columba palumbus). Ornithologische Mitteilungen 40(12): 304-306.

Prommer, M. (2008): Az esztergomi bazilika ragadozó madarai. Heliaca 2006: 82-85.

RÉKÁSI, J. (2000): Örvös galamb Columba palumbus. In: HARASZTHY, L. (szerk.): Magyarország madarai. Második, javított kiadás, Mezőgazda Kiadó, Budapest. pp. 206-207.

SiPOS, B. B. (1995): Örvös galamb (Columba palumbus) megfigyelések, Madártani Tájékoztató 1995 (január-június): 32.

Slater, P. (1995): Sefton Park Woodpigeons (1995). Merseyside Ringing Group Annual Report. Merseyside Ringing Group.

SLATER, P. (2001): Breeding ecology of a suburban population of Woodpigeons Columba palumbus in Northwest England. Bird Study 48(3): 361-366.

Solti, B. (2010): A Mátra Múzeum madártani gyüjteménye III. Németh Márton tojásgyüjtemény. Folia Historico Naturalia Musei Matraensis Supplementum 5: 2-275.

Tenovuo, R. (1967): Zur Urbanisierung der Vögel in Finnland. Annales Zoologici Fennici 4: $33-44$.

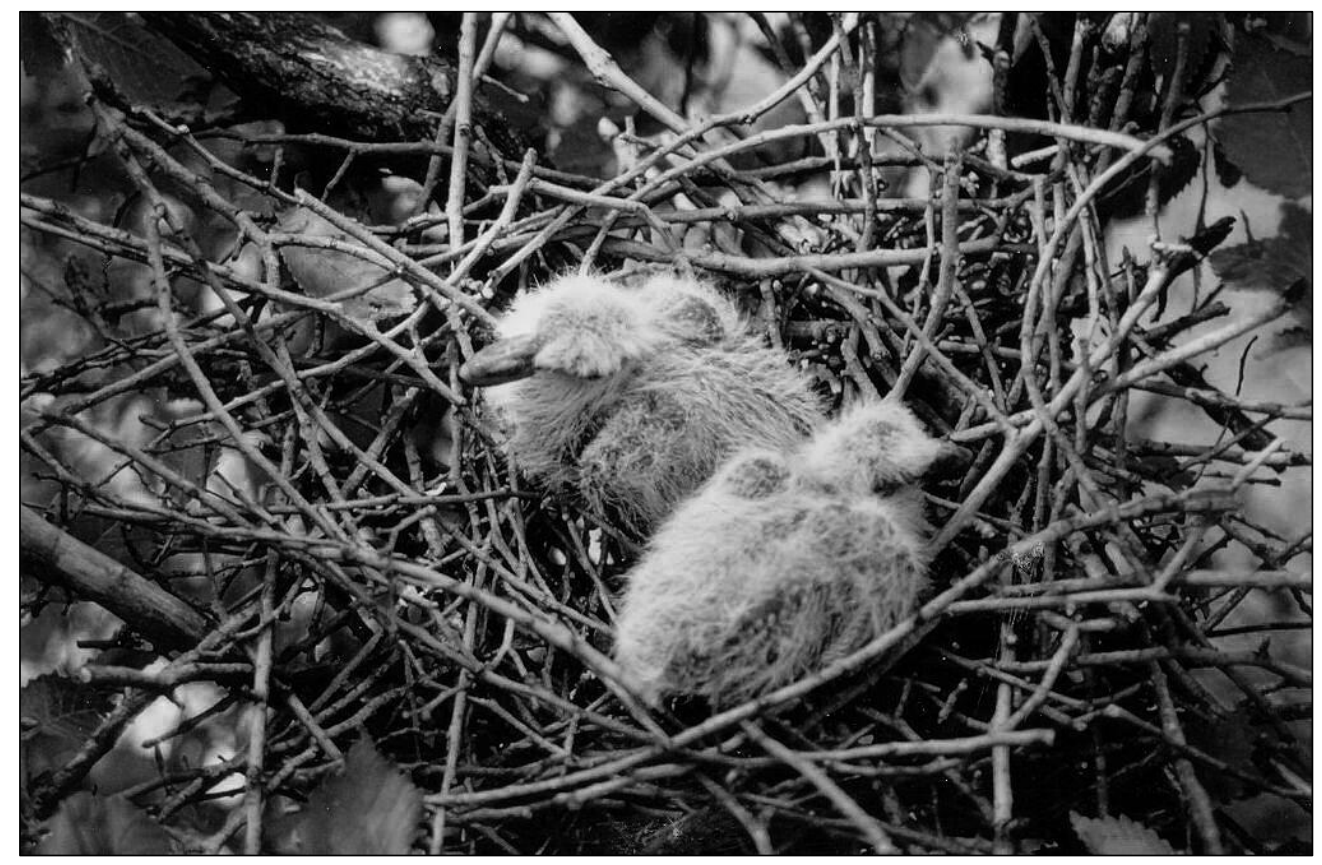

Örvös galamb fiókák (Fotó: JÁNOSKA F.) - Nestlings of Common Wood Pigeon (Photo: JÁNOSKA. F.) 